\title{
Therapeutic and Traditional Uses of Mangrove Plants
}

\author{
Vinoth $\mathbf{R}^{1}$, Kumaravel $\mathbf{S}^{2}$ and Ranganathan $\mathbf{R}^{* 3}$ \\ 1, 2,*3 Department of Botany, Annamalai University, Annamalai Nagar, Chidambaram, Tamil Nadu, India-608 002
}

\section{ABSTRACT}

Mangrove plants are specialized timbered plants growing in the swamps of tidal coastal areas and stream deltas of tropical and subtropical parts of the world. They have been utilized for medicinal and traditional purposes by the coastal folks over the years. A large number of mangrove plants grows natural and exploited especially, for use in indigenous pharmaceutical houses. Several mangroves genus produce expensive drugs which have high export potential. The utilization of plants and plant products as medicines could be traced as far back as the commencement of human civilization. Mangrove plants have been used in folklore medicines and extracts from mangrove species have prove inhibitory activity against human, animal and plant pathogens. Traditionally, the mangroves have been exploited for firewood and charcoal. Exploit has been found for mangroves in the manufacture of dwellings, furniture, boats and fishing gear, tannins for dyeing and leather production. The mangroves afford food and wide variety of traditional products and artefacts for the mangrove dwellers. The present review deals with the pharmacological activity, medicinal, traditional and produce bioactive compounds of mangrove medicinal plants.
\end{abstract}

Keywords: Mangroves, Medicinal, Pharmacological, Recourses, Traditional.

Article Info: Received 13 June 2019; $\quad$ Review Completed 21 August 2019; $\quad$ Accepted 25 August 2019; Available online 30 August 2019

\section{Cite this article as:}

Vinoth R, Kumaravel S, Ranganathan R, Therapeutic and Traditional Uses of Mangrove Plants, Journal of Drug Delivery and Therapeutics. 2019; 9(4-s):849-854 http://dx.doi.org/10.22270/jddt.v9i4-s.3457

\section{*Address for Correspondence:}

Dr. R. Ranganathan, Department of Botany, Annamalai University, Chidambaram, Tamil Nadu, India-608 002

\section{Introduction}

Historically, plants have provided a source of inspiration for novel drug compounds, as plant derived medicines have made large contributions to human health and well-being. Medicinal plants represent a rich source of antimicrobial agents $^{3}$. Because of the side effects and the resistance that pathogenic microorganisms build against antibiotics, many scientists have recently paid attention to extracts and biologically active compounds isolated from plant species used in herbal medicine ${ }^{11}$.

In developing countries, medicinal plants constitute a precious natural wealth and contribute a great contract to its health care programs. They play an important role in ensuring primary health care facilities and services to countryside people. They also serve as important healing agents as well as vital raw materials for the preparation of conventional and modern medicine ${ }^{16}$. They are biochemically unique in nature and considered as a source of novel natural products. Usually mangroves are rich in polyphenols and tannins ${ }^{9}$. Mangrove leaves contain phenols and flavonoids that serve as ultraviolet (UV) screen compounds. Substances in mangroves have long been used in folk medicines to treat diseases ${ }^{24}$. Extracts of various parts of mangrove plants have significant activity against animal, human, and plant viruses including human immunodeficiency virus ${ }^{15}$. The comprehensive uses of various mangrove plant species in human sufferings provide strong evidence of their healing power and demands further research ${ }^{8}$.

Mangrove plants contain specialized plant species that grow up at the edge between sea and land in subtropical and tropical regions of the world (Fig.1).Where they exist in high temperature, strong winds, extreme tides, high salinity and anaerobic soil ${ }^{16}$. Mangrove plant species are a typical from of common terrestrial plants in that they can tolerate high salt concentration and remain submerged in saline water ${ }^{4}$. The mangrove plants natural products, secondary metabolites produced by living organisms, present an alternative route to address the ever increasing need for new drugs, because of their low production costs, novelty and structural diversity. Plants and microbes have been viewed as the most promising sources of natural products ${ }^{1}$. Mangroves are woody trees or shrubs and the salt marsh halophytes are herbs and sledges (Fig 2). The mangrove plants are distributed in 121 countries and Pichavaram mangrove forest is one of the coastal ecosystems of Tamil Nadu, India with rich vegetation. Mangroves are used in traditional and medicine for the treatment of many diseases ${ }^{12}$. Mangrove forests are among one of the world's most productive tropical ecosystems and are highly potential. Because the ecosystem is always under stress which leads to the production of certain compounds for their survival ${ }^{18}$. 


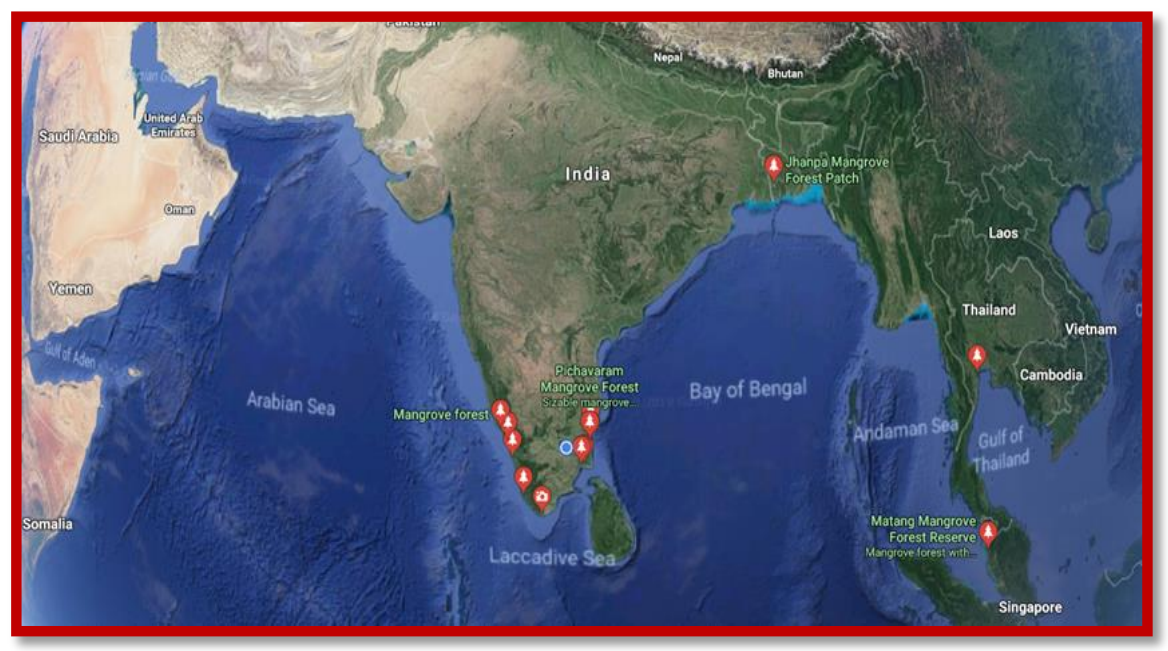

Fig.1: Map showing its satellite position in globe Asia- countries of mangrove forests.

Mangrove plants have been used in folklore medicines and extracts from mangrove species have proven inhibitory activity against human, animal and plant pathogens. Several species of mangrove produce bioactive compounds that may control microbial growth ${ }^{17}$. Secondary metabolites like alkaloids, phenolics, steroids and terpenoids have been characterized from extracts mangroves and have toxicological, pharmacological and of ecological importance. However, these studies are restricted to the mangroves of muddy region. Only few species like Pemphisacidula are growing only in coral sand substrates ${ }^{21}$. Traditionally, the mangroves have been exploited for firewood and charcoal and their uses include construction of dwellings, furniture, boats and fishing gear and production of tannins for dying and leather production. Mangroves provide food and a wide variety of traditional products and artefacts for mangrove dwellers. The mangrove leaves are useful contributors to the nutrient system of the mangrove environment. It is known that mangrove leaves contain amino acids, vitamins and minerals which helps inthe growth and development of marine organisms ${ }^{19}$.

\section{Bioactive compounds from mangroves}

Mangroves are the richest source of phytochemicals, important chemical compounds present in mangroves are carbohydrates, alcohols, amino acids, different types of fatty acids, lipids, phenolic compounds, steroids, glycosides and triterpenes. Mangrove vegetation are a affluent source of steroids, saponins, flavonoids, alkaloids and tannins ${ }^{3}$. The additional newer components like gums, glues to alkaloids, saponins and other phytochemicals are also reported to present in mangroves. Products like amino acids, carbohydrates and proteins are primary metabolism and are essential for the maintenance of life processes, while others like alkaloids, phenolics, steroids, terpenoids, are substance of secondary metabolism and have toxicological, pharmacological and ecological importance. Several mangroves found in tropical and sub-tropical regions, their general chemical constituents, in vitro bioactivity are given in (Table 1).

Table 1: General Chemical composition of mangrove plants

\begin{tabular}{|l|l|}
\hline Mangroves & General Chemical composition \\
\hline Acanthus ilicifolius & $\begin{array}{l}\text { Benzoxazoline, long chain alcohols, triterpenes, steroids, triterpenoidal saponinsalkaloid, } \\
\text { acanthicifolin }\end{array}$ \\
\hline Aegiceras corniculatum & $\begin{array}{l}\text { Benzoquinones, carotenoids, tannins,coumarins, flavonoids, } \\
\text { minerals; polyphenols, proteins, sugars, saponins, triterpenes }\end{array}$ \\
\hline Avicennia marina & Terpenoids, steroidsnaphthalene derivatives, flavones, glucosides \\
\hline Excoecaria agallocha & $\begin{array}{l}\text { Phorbol ester, flavanone, glycoside, lignin, pentosan, } \alpha \text {-cellulose saponin, tannins, phenols, } \\
\text { volatile oils }\end{array}$ \\
\hline Rhizophora apiculata & Triterpenes, steroids, and a novel triterpenoid ester \\
\hline
\end{tabular}


Morphology of medicinally used mangrove plants

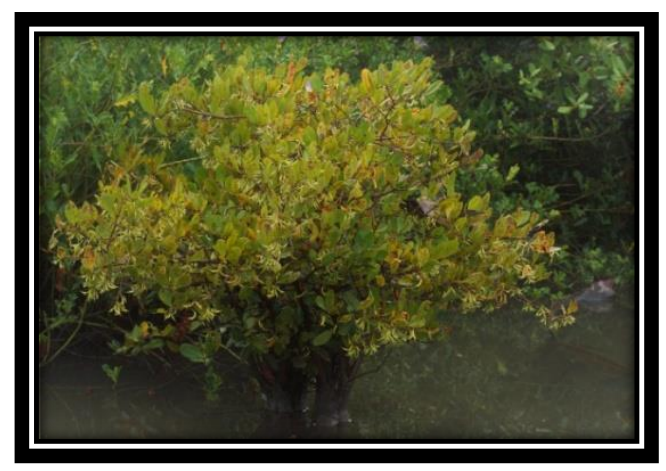

(a)

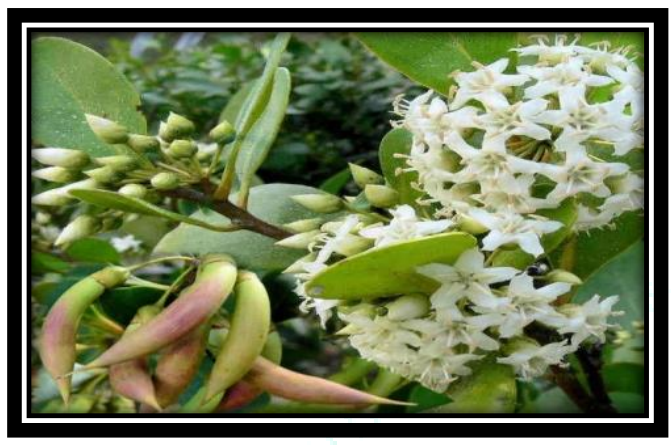

(c)

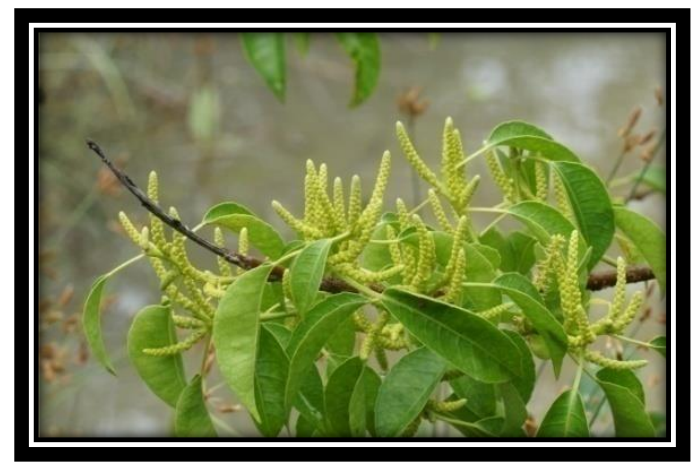

(e)

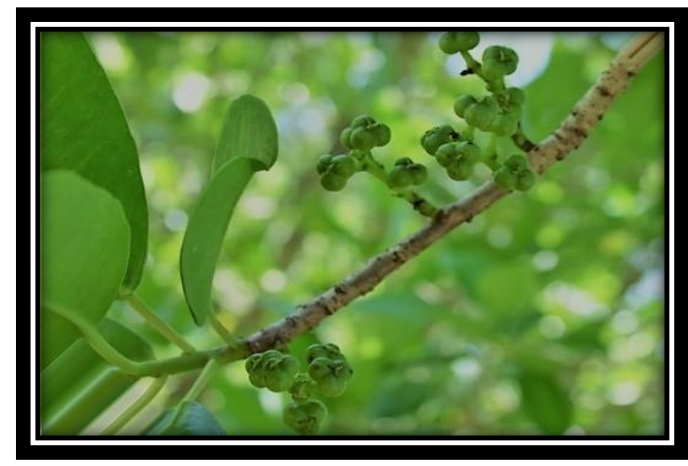

(g)

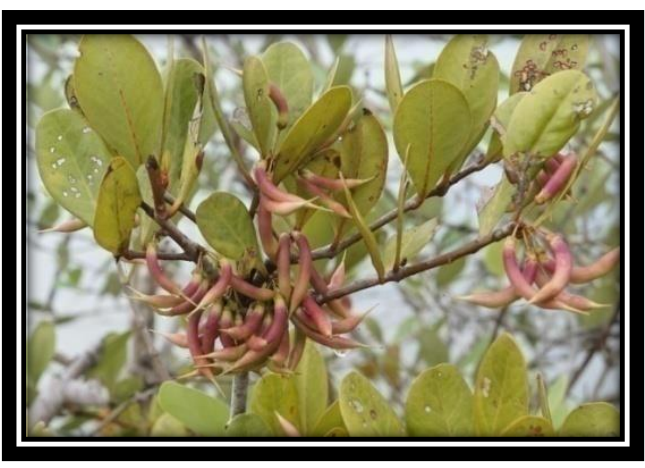

(b)

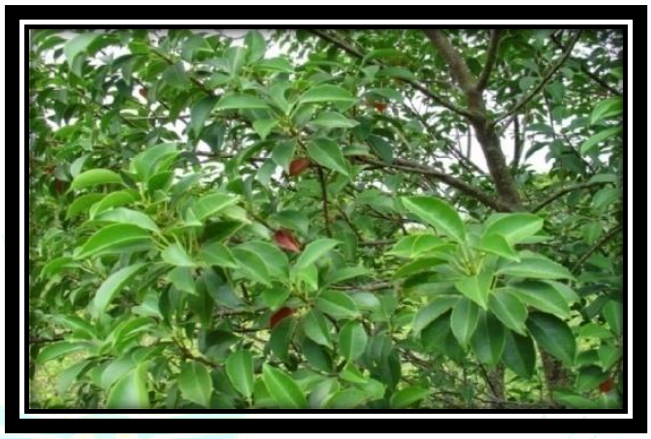

(d)

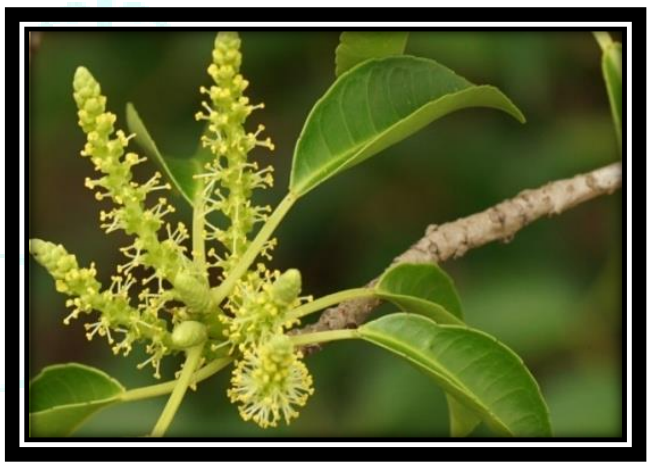

(f)

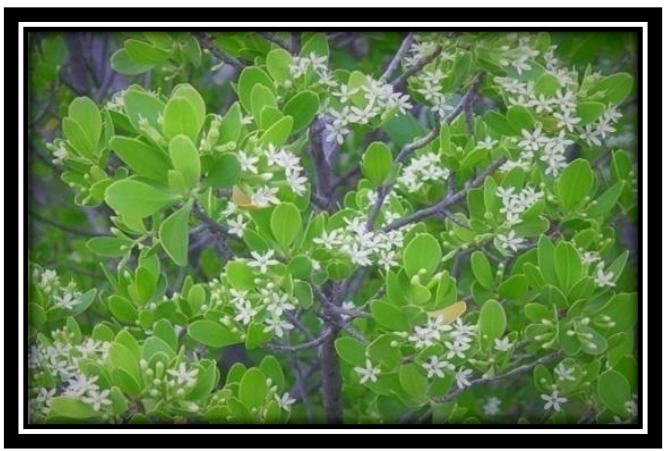

(h)

Fig.2: (a) Aegicers corniculatum Blanco. entire plant; (b) A. corniculatum fruit; (c) A. corniculatum flowers; (d) Excoecaria agallocha L. entire plant; (e)E. agallocha male flower;(f)E. agallocha male flower;(g) E. agallocha female fruit; (h) Lumitzera recemosa Willd. entire plant; 


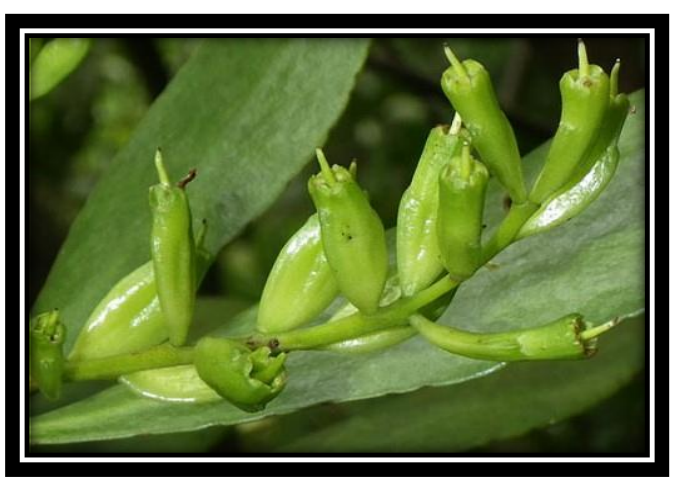

(i)

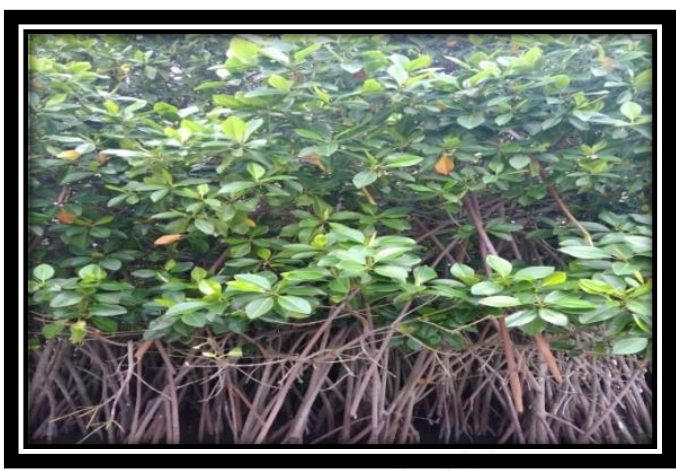

(k)

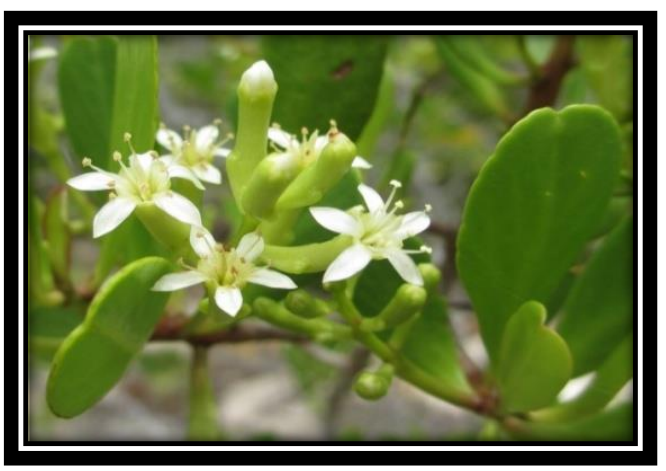

(j)

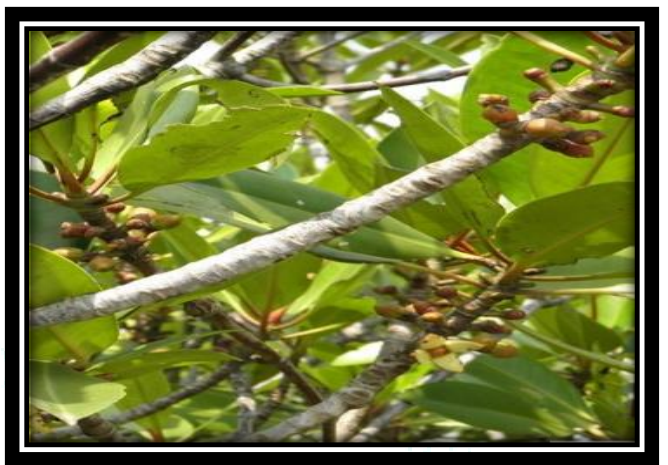

(l)

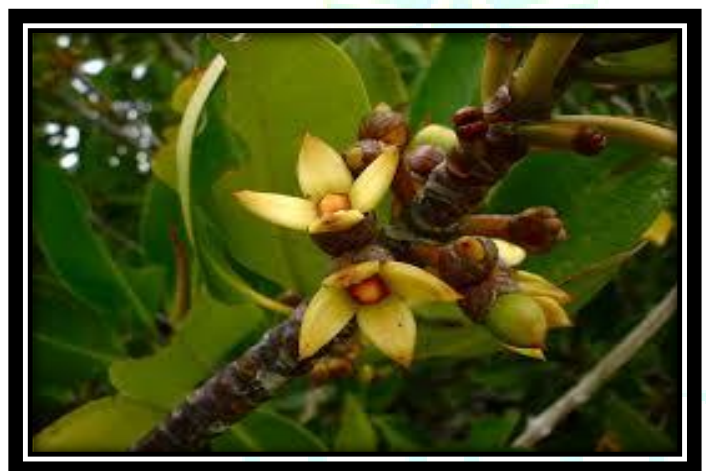

(m)

Fig.2: (i) L. recemosa fruit; (j) L.recemosa flower; (k) Rhizhophora apiculata Blue. entire plant; (l) R. apiculata flowering stage; (m) R.apiculata flower.

\section{Anti-diabetic Mangroves}

\section{Excoecaria agallocha}

Traditionally it is used as uterotonic, in the treatment of epilepsy, conjunctivitis, dermatitis, hematuria, leprosy, toothache. Phytochemical screening shows the presence of phorbol ester, flavanone, glycoside, dichloromethane, lignin, pentosan, $\alpha$ cellulose saponin, tannins, phenols, volatile oils ${ }^{27}$.Pharmacological investigation of the various extracts of the plant shows antibacterial, antioxidant, anti-diabetic, antibacterial, antinociceptive effects it is also reported it has some impact on the treatment of mosquito borne diseases and pandemic diseases.

\section{Rhizophora apiculata}

Viviparous seeds are edible. Wood is a source of tannin and used as a substitute for petroleum coke. Tannin from bark is used as mosquito repellent. It is also used as astringent, for the treatment of diarrhoea, nausea and vomiting, antiseptic, antihemorrhagic, cure for typhoid fever and also for the treatment of diabetics the phyto chemical screening shows the presence triterpenes, steroids, and a novel triterpenoid ester.

\section{Medicinal uses of mangroves}

Acanthus ilicifolius are used in Ayurveda, the plant is known as Sahachara. According to Nadkarni the drug is astringent and makes a good nervine tonic, expectorant, and stimulant. The root is expectorant, and is used in coughs and asthma. The root, boiled in milk, is largely used in leucorrhoea and general debility. The Siamese and Indo-Chinese consider the roots to be cordial and attenuant, and useful in paralysis and asthma. The tender shoots and leaves are used in India for bite. In Goa, the leaves, which abound in mucilage, are used as an emollient fomentation in rheumatism and neuralgia (Table 2). 
Table 2: Medicinal uses of mangroves and halophytes

\begin{tabular}{|l|l|}
\hline \multicolumn{1}{|c|}{ Mangrove plant names } & \multicolumn{1}{c|}{ Medicinal uses } \\
\hline Acanthus ilicifolius & $\begin{array}{l}\text { To treat paralysis, asthma, diuretic, dyspepsia, hepatitis, leprosy, rheumatic } \\
\text { pains. analgesic, anti-inflammatory, leishmanicidal }\end{array}$ \\
\hline Aegiceras corniculatum & Cure for asthma, diabetes, rheumatism, fish poison \\
\hline Avicennia marina & Cure for skin diseases \\
\hline Avicennia officinalis & Aphrodisiac, diuretic, hepatitis and leprosy. \\
\hline Bruguiera gymnorhiza & Eye diseases \\
\hline Bruguiera parviflora & Antitumor. \\
\hline Ceriops decandra & Hepatitis and ulcers \\
\hline Lumnitzera racemosa & Antifertility, asthma, diabetes and snake bite \\
\hline Rhizophora mangle & $\begin{array}{l}\text { Angina, boils and fungal infections, antiseptic, diarrhoea, dysentery, elephantiasis, } \\
\text { fever, malaria, leprosy, minor bruises, plaster for fractured bones and tuberculosis. }\end{array}$ \\
\hline Rhizophora mucronata & Elephantiasis, febrifuge, haematoma, hepatitis and ulcers. \\
\hline Salicornia brachiate & Hepatitis \\
\hline Sesuvium portulacastrum & Hepatitis \\
\hline Sueda maritima & Hepatitis \\
\hline Sueda monoica & Hepatitis \\
\hline
\end{tabular}

\section{Antioxidant activity}

Antioxidants are frequently originate in therapeutic plants, vegetables, and fruits. Antioxidants have been consider capable agents for the anticipation and treatment of reactive oxygen species correlated diseases such as cancer, cardiovascular disease, atherosclerosis, hypertension, ischemia/reperfusion injury, diabetes mellitus, neurodegenerative diseases, rheumatoid arthritis, and aging23. Endophytic colonization of Trichoderma was initiate to be elevated in mangrove leaves of Aegiceras corniculatum than the other mangroves of Andaman and Nicobar Islands and was demonstrated to be with probable for antioxidant activity ${ }^{10}$.

\section{Anticancer Activity}

Phytochemical appraisal of the leaves concentrate of Heritierafomes announced the presence of saponins, diminishing sugars, alkaloids, glycosides, flavonoids, tannins, steroids, and gums ${ }^{14}$. What's more, proanthocyanidins (bioactive mixes, present in different restorative plants including Heritierafomes) supposedly have antiviral, antibacterial, protein hindering, cell reinforcement, and anticarcinogen properties ${ }^{20}$. Numerous other mangrove species have been reported with anticancer potential. Antitumor activity of 3-chlorodeoxylapachol, a naphthoquinone obtain beginning Avicennia germinans has been demonstrated 25 .

\section{Traditional exploitation}

In villages the entire encircling the world, folks are dependent on mangroves for timber and firewood, to build dwellings and lattice, furniture, studs for houses, rafters, joists, telegraph poles, fences, bridges, railway sleepers, poles for fish traps, paddles and rafts, canoes and boats26,5,6,13,7,22. In Sri Lanka, straight stems of Ceriops tagal, Rhiziphora and Bruguiera species are used to construct the frames of the thatched roofs and windowpane frames. The wattle of the mire walls of houses is prepared with timber from the exceeding species as well as Sonneratia and the timber since coconut trees is extensively used as rafters ${ }^{2}$. In Malaysia the production of charcoal is now one of the most important forms of mangrove utilization. The best charcoal with highest caloric power, exceptional slow-burning properties and no smoke is that obtained from Rhizophora billets. For this reason, present day Pakistan, Rhizophora wood is used to fuel the boilers of the locomotives. In Sri Lanka coconut shells are "combusted" in limited supply of air to produce an excellent charcoal and "activated" carbon which is used in various industries. It is still being used by the villagers to heat the "irons" to press clothes. In rural "cottage" industries, fuel wood or charcoal have viable and valuable economic uses, such as in drying coffee or curing fish. Large scale conversion of mangroves for wood chip production began in East Malaysia and Indonesia during the 1970s. In 1971almost 50,000 ha were licensed in to produce wood chips, mainly for export to Japan. Malaysia halted the practice after 15 years, but mangrove woodchips are still a major export from Kalimantan accounting for the annual loss of thousands of hectares of mangroves ${ }^{28}$.

\section{Conclusion}

Mangrove ecosystems present an exclusive and expensive assortment of resources, services and to confident extent products, but they have always been an undervalued resource. The pharmacological impending of the oceanic habitats of Indian coastline as well as mangrove forests still remains mostly un explored. Marine natural product bioprospecting has yield a amount of medicine in recent years. Endophtyic microbes are also now being predictable as a new and defectively explored source of bioactive compounds. This review shows that many endophytes inhabiting the dissimilar mangrove forests of the world, essentially fungi, have proven themselves to be prosperous sources of recent bioactive metabolites. Traditionally the mangroves are used as firewood and charcoal and moreover used for manufacture of dwellings, furniture, boats and fishing gear and production of tannins for dying and leather production, solitary few species are used traditionally for therapeutic diseases. It is reported that various of the species originate in world has anti-diabetic activity, synthetic anti-diabetic agents had several disagreeable elevation effects therefore the screening and the development of newer and safer anti-diabetic representative commencing mangroves have immense scope in the natural products explore. These plants require instantaneous consideration for carrying out detailed chemical and pharmacological evaluations. Such investigations can lead to the finding of narrative bioactive compounds to facilitate determination assist to consider the efficiency of herbal remedies. 


\section{References}

1. Alvin A, Miller KI, Neilan BA. Exploring the potential of endophytes from medicinal plants as sources of antimycobacterial compounds. Microbiol Res (2014); 169:483-95.

2. Amarasinghe, M.D. (1988). Mangrove ecosystems: Occasional Papers No 3. Socio-economic status of the human communities of selected mangrove areas on the west coast of Sri Lanka, UNESCO publications, New Delhi, 19 pp.

3. Bandaranyake, W.M. (1995). Survey of mangrove plants from Northern Australia for phytochemical constituents and UVabsorbing compounds. Current Topics in Phytochemistry (Life Science Advances) 14: 69-78.

4. Bhimba, B.V., J. Meenupriya, E.L. Joel, D.E. Naveena,S. Kumar and M. Thangaraj, (2010). Antibacterial activity and characterization of secondary metabolites isolated from mangrove plant Avicennia officinalis. Asian Pacific Journal of Tropical Medicine, 3(7): 544-546.

5. FAO (1982). Management and Utilization of Mangrove in Asia and Pacific. Food and Agriculture Organization of the United Nations, FAO Environment Paper No.3, Rome, 26 pp.

6. FAO (1985). Mangrove management in Thailand, Malaysia and Indonesia. Food and Agriculture Organization of the United Nations, FAO Environment Paper No.4, Rome, 59 pp.

7. Field, C. (1995). Journeys amongst mangroves. International Society for Mangrove.

8. Imran Mahmud,1 Md Khirul Islam,1 Sanjib Saha,1 Apurba Kumar Barman,1 Md Mustafizur Rahman,1 Md Anisuzzman,1 Taufiq Rahman,2 Abdullah Al-Nahain,3 Rownak Jahan,4 and Mohammed Rahmatullah3, International Scholarly Research Notices Volume (2014).

9. K. Kathiresan and V. Ravi, "Seasonal changes in tannin content of mangrove leaves," Indian Forester, vol. 116, no. 5, pp. 390392, (1990).

10. Kandasamy S, Kandasamy K. Antioxident activity of the mangrove endophytic fungus (Trichoderma $s p$ ). J Coastal Life Med (2014); 2(7):566-70.

11. Kilani, A.M., 2006. Antibacterial assessment of whole stem bark of Vitex doniana against some Enterobactriaceae. African Journal of Biotechnology, 5: 958-959

12. Kirtikar, K.R. and B.D. Basu, (1991). Indian medicinal plants. Lalit Mohan Basu Publishers, Allahabad, India, pp: 1-2793 IIV.

13. Knox, G.A. and Miyabara, T. (1984). Coastal zone resource development and conservation in South East Asia, with special reference to Indonesia. UNESCO, Jakarta, Indonesia, 182 pp.

14. M. A. Hossain, S. Panthi, M. Asadujjaman, S. R. Khan, F. Ferdous, and S. K. Sadhu, "Phytochemical and pharmacological assessment of the ethanol leaves extract of Heritiera fomes Buch. Ham. (Family- Sterculiaceae)," Journal of Porphyrins and Phthalocyanines, vol. 2, pp. 95-101, (2013).

15. M. Premanathan, H. Nakashima, K. Kathiresan, N. Rajendran,and N. Yamamoto, "In Vitro anti human immuno deficiency virus activity of mangrove plants," Indian Journal of Medical Research, vol. 103, pp. 278-281, (1996).

16. M. Spalding, "Te global distribution and status of mangrove ecosystems," in International News Letter of Coastal Management-Intercoast Network, pp. 20-21, 1st edition, (1997).

17. Miki, T., T. Sakaki, M. Shibata, Y. Inukai, M. Hirosue, Y. Ikema and S. Yaga, (1994). Soxhlet extraction of mangrove and biological activities of extracts. Kyushu Kogyo Gijutsu Kenkyusho Hokoku, 53: 3347-3352

18. Mishra, P.K., J.R. Sahu and V.P. Upadhyay, (2005). Species diversity in Bhitarkanika mangrove ecosystem in Orissa, India. Lyonia, 8(1): 73-87.

19. Muhammed Habeebulla and MalarkodiVelraj (2018) Potential anti-diabetic mangroves in Kerala, India: A Review Int. J. Res. Ayurveda Pharm. 9 (4), DOI: 10.7897/2277 4343.094142.

20. P. M. Aron and J. A. Kennedy, "Flavan-3-ols: nature, occurrence and biological activity," Molecular Nutrition and Food Research, vol. 52, no. 1, pp. 79-104, 2008.

21. Philip, K., S.K. Sinniah and S. Muniandy, (2009). Antimicrobial peptides in aqueous and ethanolic extracts from microbial, plant and fermented sources. Biotechnology, 8(2): 248-253.

22. Rasolofo, M.V., (1997). Use of mangroves by traditional fishermen in Madagascar. Mangroves and Salt Marshes 1: 243-253

23. Valko M, Leibfritz D, Moncol J, Cronin MTD, Mazur M, Telser J. Free radicals and antioxidants in normal physiological functions and human disease. Int J Biochem Cell Biol (2007); 39(1):44-84.

24. W. M. Bandaranayake, "medicinal uses of mangroves," Mangroves and Salt Marshes, vol. 2, no. 3, pp. 133- 148, (1998).

25. W. P. Jones, T. Lobo-Echeverri,Q.Mi et al., "Antitumour activity of 3-chlorodeoxylapachol, a naphthoquinone from Avicennia germinans collected from an experimental plot in southern Florida," Journal of Pharmacy and Pharmacology, vol. 57, no. 9, pp. 1101-1108, (2005).

26. Walsh, G.E. (1977). Exploitation of Mangal. In: Chapman, V.J. (ed), Ecosystems of the World. Elsevier Scientific, New York, pp. 347-35.

27. Zou JH, Dai J Chen X, Yuan JQ. Pentacycli. Triterpenoids from leaves of Excoecaria agallocha. Chem Pharm Bull (2006) 54:920-1. 